\title{
Site suitability analysis for decentralized sustainable solid waste management system for Coimbatore city using GIS.
}

\section{Análisis de idoneidad del sitio para un sistema descentralizado de gestión de residuos sólidos sostenible para la ciudad de Coimbatore utilizando SIG.}

\author{
Ms.P.Poornima ${ }^{1}$, Dr.R.Nithya ${ }^{2}$ \\ Department of Civil Engineering Avinashilingam Institute for Home Science and Higher \\ Education School of Engineering, Coimbatore, Tamil Nadu \\ email(1): 18phevf001@avinuty.ac.in; email(2): nithya_civil@avinuty.ac.in
}

\section{ABSTRACT}

The effective solid waste management in a developing country like India has become an essential concern of the society. Municipality and corporation have framed many policies and municipal solid waste rules for a sustainable solid waste management, but the increase in population and urbanization leads to many challenges in implementing an effective system. Disposal of waste is an important action in solid waste management but due to many flaws in system the centralized disposal of waste is not effective. In this research the site selection for decentralized processing unit zone wise is done using GIS and weighted overlay analysis. The weighted overlay analysis is done by using thematic layers like land use land cover, geomorphology, geology, soil, lineaments, ground water depth, distance from water bodies, distance from railway track, drainage density, road density ,distance from roads are used as inventory maps to arrive the suitable area to carry out decentralized solid waste management. The results revealed the suitable area in sqkm under five classifications as highly suitable, high to moderately suitable, moderately suitable, poorly suitable and not suitable.

Keywords: site suitability, south zone, Coimbatore decentralized waste management, weighted overlay analysis.

\section{RESUMEN}

La gestión eficaz de los residuos sólidos en un país en desarrollo como India se ha convertido en una preocupación fundamental de la sociedad. El municipio y la corporación 
Sustainability, Agri, Food and Environmental Research, (ISSN: 0719-3726), 10(X), 2022:

http://dx.doi.org/

han enmarcado muchas políticas y reglas municipales de residuos sólidos para una gestión sostenible de los residuos sólidos, pero el aumento de la población y la urbanización lleva a muchos desafíos en la implementación de un sistema eficaz. La eliminación de desechos es una acción importante en la gestión de desechos sólidos, pero debido a muchas fallas en el sistema, la eliminación centralizada de desechos no es efectiva. En esta investigación, la selección del sitio para la zona de la unidad de procesamiento descentralizada se realiza utilizando GIS y análisis de superposición ponderada. El análisis de superposición ponderada se realiza mediante el uso de capas temáticas como la cobertura del suelo de uso del suelo, geomorfología, geología, suelo, lineamientos, profundidad del agua subterránea, distancia de los cuerpos de agua, distancia de la vía férrea, densidad de drenaje, densidad de la carretera, distancia desde las carreteras se utilizan mapas de inventario para llegar al área idónea para realizar el manejo descentralizado de residuos sólidos. Los resultados revelaron el área adecuada en kilómetros cuadrados bajo cinco clasificaciones como altamente adecuada, de alta a moderadamente adecuada, moderadamente adecuada, poco adecuada y no adecuada.

Palabras clave: idoneidad del sitio, zona sur, gestión descentralizada de residuos de Coimbatore, análisis de superposición ponderada.

\section{INTRODUCTION}

The decentralized solid waste management will be a sustainable method to avoid unnecessary dumping and the processing of waste then and there can be an effective waste handling method. The identification of suitable land in each zone can be an initiative to progress decentralized processing system for municipal solid waste. The implementation of technology like GIS tool can give a permanent solution and support sustainable development of city. Urban developments have increased the migration of peoples towards major cities and which leads to demand for more alternative technology for betterment of city. Decentralized waste management will be a better system for growing population.

The MSW amount is expected to increase significantly in the near future as the country strives to attain an industrialized nation status by the year 2020 (Sharma and Shah, 2005; CPCB, 2004; Shekdar et al., 1992). Vuppala et al., (2006) adopted the analytical hierarchy process to identify the optimum landfill site location for municipal solid waste disposal.

Taha et al., (2011) identified the non-engineered landfill sites at Ampar Tenang and Bukit Tagar in the state of Selangor, Malaysia. Makan et al., (2012) analyzed the impact of the solid waste at landfill through laboratory tests and the most suitable landfill site location in Azemmour, Morocco based on the PROMETHEE method. The result was compared with an 
Sustainability, Agri, Food and Environmental Research, (ISSN: 0719-3726), 10(X), 2022:

http://dx.doi.org/

AHP method to validate the selected alternative landfill site in Azemmour. Eskandari et al., (2013) applied the integrated GIS and AHP for the identification of the landfill site, the methodology explains the weight assigned to each thematic feature in detail. The assigning of weight may vary from one location to another due to the location factor.

Das et al., (2014) estimated the municipal solid waste generation and future trends for Kolkata in India. The estimation of future MSW generation is essential to manage the population and urban growth in cities. The study explains the correlation analysis of the different solid waste generation factors and the future waste generation prediction in Kolkata. Soltani et al., (2015) developed a multi-criteria decision analysis which was used with the support of multiple stakeholders to identify the municipal solid waste management problems and suitable solutions. The analysis result is used to resolve more complicated problems in municipal solid waste management. The research proposed multi-objective mathematical programming to define the probability of waste facilities in the Italian regions. Pandey et al., (2016) identified the amount of energy extracted from municipal solid waste (MSW) in Bhopal city, India. In this study MSW was classified into different materials like paper, wood, clothes, polythene, etc., to identify the qualitative and quantitative measurement of MSW in Bhopal city. There are many literatures for landfill site selection but the selection of site requires multi objective approach the site should be feasible in many aspects like ecological, social, economical and technical consideration (saaty)

The present study focuses to assess the available area of land for installation of decentralized solid waste processing unit for Coimbatore city. The Coimbatore Corporation is divided into five zones and 100 wards for administrative purpose. In which the south zone is taken as study area and analysed for potential sites. The thematic maps and ranks are assigned based on the influencing features in each thematic maps and municipal solid waste management rules.

\section{MATERIAL AND METHODS}

Coimbatore city is famously known as Manchester of South India is located in the Western part of Tamil Nadu, India. Coimbatore City was established as a Municipality in November 1866 with a population of 24,000 covering an extent of 257 sq. km (Figure 1 ). The status of the city has since been elevated as a municipal corporation from 1-5-1981. The present population of the city is approximately 13 lakhs including a free population of around 1.5 lakhs. Out of this, the developed area is 5530.30 hectares, i.e., $52.40 \%$ of the total area. The remaining $47.67 \%$ constitute undeveloped area comprising of agricultural, unused vacant lands, water bodies, and wastelands. 
Sustainability, Agri, Food and Environmental Research, (ISSN: 0719-3726), 10(X), 2022:

http://dx.doi.org/

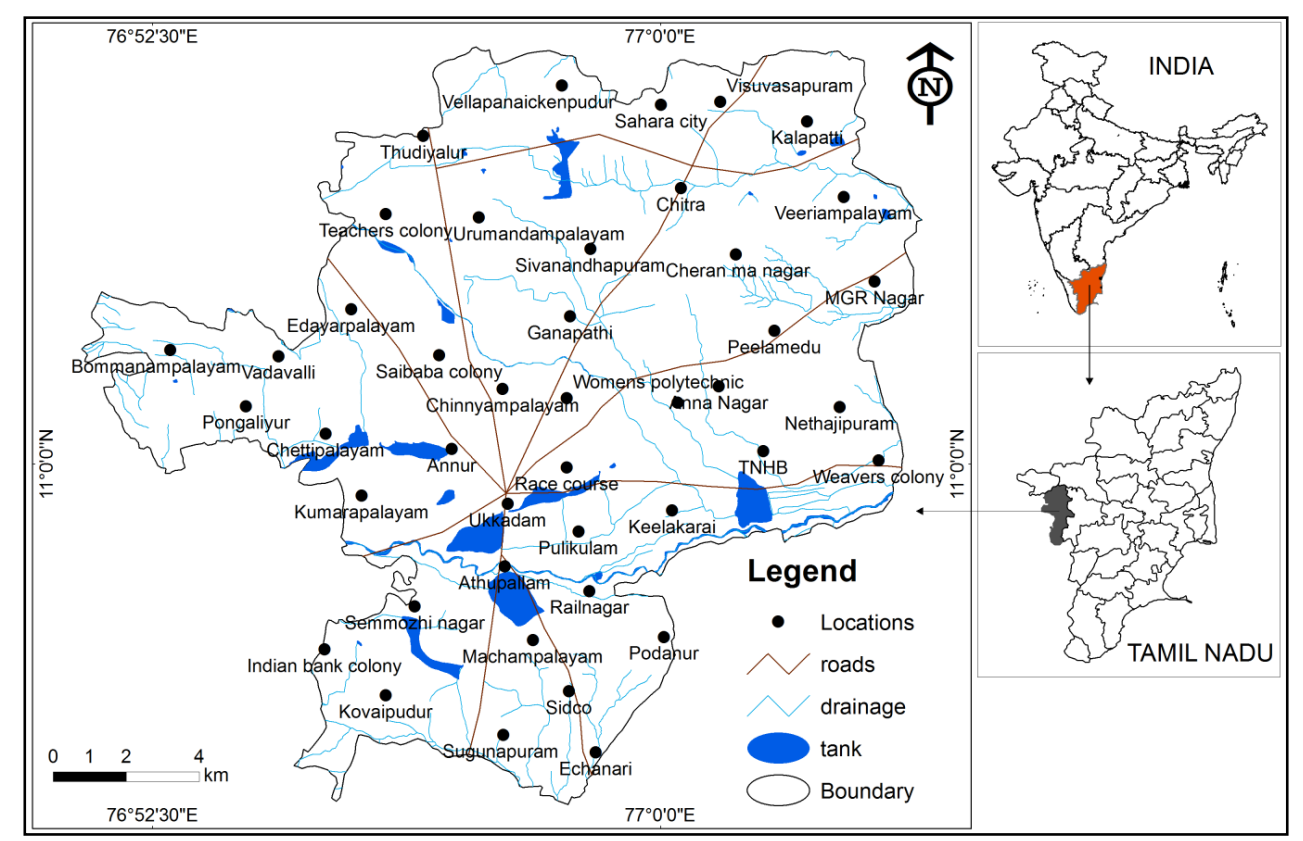

Fig 1 Location of the study area

For site suitability assessment important influencing factors such as land use, geomorphology, geology, soil, lineament density, groundwater depth, distance from water bodies, road density, distance from railway track, slope (degree) and drainage density are considered for weighted overlay analysis. The base map prepared from India toposheet. Satellite image from IRS P6 LISS III have utilized for preparation of land use, geomorphology, lineament and water body extraction. Geological features have prepared from GIS 1998 and soil information gathered from Soil survey of India map. Using buffer tool the distance from water bodies have prepared. The SRTM DEM $90 \mathrm{~m}$ resolution satellite data utilized for preparation of slope map. The maps are digitized using ARC GIS software and distance calculation is done by buffer analysis.

Parameters considered for site selection:

Land Use: The selection of potential site must fulfill many environmental and legislation conditions. In land use, five classifications are made as agricultural use, commercial use, residential area, educational use and industrial use. The rank assigned for land use is based on MSW rule 2016 and other important criteria. Rank 1 indicates the highest priority, rank 2 indicate medium priority and the rank 5 indicate the low priority. Based on the feature importance the rank is assigned from 1 to 5 in land use classification (Table 1 ). 
Sustainability, Agri, Food and Environmental Research, (ISSN: 0719-3726), 10(X), 2022:

http://dx.doi.org/

Table 1. Land Use Classification

\begin{tabular}{llcl}
\hline Parameter & Classification & Ranks & Weights \\
\hline Land use & Agricultural use & 3 & 14 \\
& Commercial use & 4 & \\
& Educational use & 1 & \\
& Industrial use & 2 & \\
& Residential use & 2 & \\
\hline
\end{tabular}

- Geomorphology

The presence of geomorphological features is classified into 7 major classifications as bazada, colluvial fan, flood plain, inselberg complex, pediment buried, pediplain buried and structural hills. The pediplain weathered is more suitable due to its drainage property which is essential for discharge of effluents from waste deposit. The assigning of weight to each layer depends upon the constraints and important of the individual parameter in that layer. (Table 2)

Table 2. Geomorphology

\begin{tabular}{llll}
\hline Parameter & Classification & Ranks & Weights \\
\hline Geomorphology & Structural Hills & 4 & 10 \\
& Pediplain & 1 & \\
& Weathered & & \\
& Pediment buried & 1 & \\
Bazada & 5 & \\
Colluvial fan & 2 & \\
& Flood Plain & 2 & \\
& Inselberg & 4 & \\
Complex & \\
\hline
\end{tabular}

- Geology

The geological settlements in the study area were identified as granite, granitoid gneiss, hornblende biotite gneiss, quartz vein, sand and silt, sandstone and shale, and ultrabasic rocks. According to the importance of the geological features ranks has been 
Sustainability, Agri, Food and Environmental Research, (ISSN: 0719-3726), 10(X), 2022:

http://dx.doi.org/

assigned. The presence of sand and silt is optimum for a solid waste processing unit site, hence it has been ranked as rank 1 . (Table 3 )

Table 3. Geology Classification

\begin{tabular}{llll}
\hline Parameter & Classification & Ranks & Weights \\
\hline Geology & Granite & 4 & 12 \\
& Granitoid gneiss & 4 & \\
& Hornblende biotite & 4 & \\
& gneiss & & \\
Quartz vein & 5 & \\
& Sand and silt & 1 & \\
& Sandstone and shale & 1 & \\
& Ultrabasic rocks & 3 & \\
\hline
\end{tabular}

- Soil

The availability of vertisols is optimum for the landfill because of its expansive property. Based on the soil characteristics rank has been assigned from 1 to 5.The rank assigned for vertisols is 1 due to its expansion property. For inceptisols rank, 2 were assigned in the study area. (Table 4)

Table 4. Soil Classification

\begin{tabular}{llll}
\hline Parameter & Classification & Ranks & Weights \\
\hline Soil & Alfisols & 4 & 9 \\
& Entisols & 3 & \\
& Inceptisols & 2 & \\
& Vertisols & 1 & \\
& Reserve Forest & 5 & \\
\hline
\end{tabular}

\section{- $\quad$ Lineament}

The chances of infiltration of leachate are possible due to the lineament. The guidelines provide the landfill site should be low density in the lineaments. The rank assigned for lineament density from 1 to 5 . The faults may allow the leachate to contaminate the groundwater. (Table 5)Euclidean distance metric analysis is one of the useful techniques to identify the impact distance of the each linear feature (Demesouka et al., 2013). 
Sustainability, Agri, Food and Environmental Research, (ISSN: 0719-3726), 10(X), 2022:

http://dx.doi.org/

Table 5. Lineament Classification

\begin{tabular}{llll}
\hline Parameter & Classification & Ranks & Weights \\
\hline LD & $0-0.20 \mathrm{~km} / \mathrm{sq} . \mathrm{km}$ & 5 & 9 \\
& $0.20-0.57$ & 4 & \\
$0.57-0.94$ & 3 & \\
$0.94-1.52$ & 2 & \\
$1.52-2.65$ & 1 & \\
\hline
\end{tabular}

- $\quad$ Groundwater Depth

The groundwater table is identified by studying 43 different groundwater bore well location. All the groundwater level is added as attribute information about the groundwater location data. The spatial analysis was performed to the groundwater table level. By using GIS analysis technique groundwater contour map was prepared to understand the groundwater depth level in the study area. The groundwater availability below the ground level may vary from $4 \mathrm{~m}$ to $16 \mathrm{~m}$. The rank assigned for groundwater below ground level (BGL) 11 to $16 \mathrm{~m}$ depth as 3 due to more possibilities of contamination .(Table 6)

Table 6. Groundwater Depth Classification

\begin{tabular}{llll}
\hline Parameter & Classification & Ranks & Weights \\
\hline GWD & $4.29-7.46$ & 5 & 10 \\
& $7.46-8.84$ & 4 & \\
& $8.94-10.11$ & 3 & \\
& $10.11-11.73$ & 2 & \\
& $11.73-16.09$ & 1 & \\
\hline
\end{tabular}

- $\quad$ Distance from Water Bodies

The MSW management rule provides the guidelines for the operation of landfills within 500m distance from the water bodies should be objectionable. The development of the proper model is required to identify the appropriate disposal site based on many criteria. The rank assigned 1 for the location which is $1000 \mathrm{~m}$ away from the water body. The rank 2 assigned to the location 500 to $1000 \mathrm{~m}$ and the rank 5 for 0 to $500 \mathrm{~m}$ away from the water body. The guidelines indicate the selection of landfill site should be $100 \mathrm{~m}$ away from the river and $200 \mathrm{~m}$ away from the water bodies like a pond, lake etc.(Table 7 ) 
Sustainability, Agri, Food and Environmental Research, (ISSN: 0719-3726), 10(X), 2022:

http://dx.doi.org/

Table 7. Distance from water bodies classification

\begin{tabular}{llll}
\hline Parameter & Classification & Ranks & Weights \\
& & & \\
\hline DWB & $>1000 \mathrm{~m}$ & 1 & 12 \\
& $750-1000 \mathrm{~m}$ & 2 & \\
& $500-750 \mathrm{~m}$ & 3 & \\
& $250-500 \mathrm{~m}$ & 4 & \\
& $<250 \mathrm{~m}$ & 5 & \\
\hline
\end{tabular}

- $\quad$ Road Density

The road density is essential criteria, according to the guideline; the centre line of the road should be away from low density to the disposal site. The rank as being assigned 1 to 5 based on the guidelines Road network density analysis is widely used in intelligent transportation, urban planning and automatic map generalization.(Table 8)

Table 8. Road density classification

\begin{tabular}{llll}
\hline Parameter & Classification & Ranks & Weights \\
& & & \\
\hline RD & $0-.0 .88 \mathrm{~km} / \mathrm{sq} . \mathrm{km}$ & 1 & 5 \\
& $0.88-2.50$ & 2 & \\
& $2.50-4.75$ & 3 & \\
& $4.75-8.41$ & 4 & \\
& $8.41-13.37$ & 5 & \\
\hline
\end{tabular}

\section{- $\quad$ Slope}

The presence of slope will influence the direction of leachate flow in disposal site. The higher slope will make contamination in the particular area in processing unit site (Table 9). The implementation of recent technologies will reduce the tedious conventional process of landfill site selection (Eiselt et al., 2014). The rank of the slope was assigned as less than 0.99 slope as 1,20 to 36 degree slope as 5 . Greater than 11 degree slope will influence more runoff in a certain direction in the Composting Yard. 
Sustainability, Agri, Food and Environmental Research, (ISSN: 0719-3726), 10(X), 2022:

http://dx.doi.org/

Table 9. Slope classification

\begin{tabular}{llll}
\hline Parameter & Classification & Ranks & Weights \\
\hline Slope & $0-0.99$ & 1 & 7 \\
& $0.99-4.28$ & 2 & \\
& $4.28-11.28$ & 3 & \\
& $11.28-20.71$ & 4 & \\
& $20.71-36.56$ & 5 & \\
\hline
\end{tabular}

- $\quad$ Distance From Railway Track

The railway track study is essential for any regional or local planning. It has been restricted to implement many structures nearby to the structure. Coimbatore railway track is running in the North-South direction, which was digitized. Railway track location map played a vital role at the time for selecting an alternate landfill site and transfer station location site. The Southern railway track is running in the study area, according to the guidelines the centre line of the railway track should be away from $500 \mathrm{~m}$ to the disposal site. The rank as being assigned 0 to $500 \mathrm{~m}$ as 3, 500 to $1000 \mathrm{~m}$ as 2 and greater than $1000 \mathrm{~m}$ as 1 based on the guidelines. (Table 10)

Table 10. Distance from railway track classification

\begin{tabular}{llll}
\hline Parameter & Classification & Ranks & Weights \\
& & & \\
\hline DRR & $>1000 \mathrm{~m}$ & 1 & 6 \\
& $750-1000 \mathrm{~m}$ & 2 & \\
& $500-750 \mathrm{~m}$ & 3 & \\
& $250-500 \mathrm{~m}$ & 4 & \\
& $<250 \mathrm{~m}$ & 5 & \\
\hline
\end{tabular}

- $\quad$ Drainage Density

The drainage availability in the study area was identified by using a drainage map. The drainage density is important criteria for landfill site selection. The landfill site location should be away from the drainage. In this case, the distance 0 to $30 \mathrm{~m}$ away from the drainage is considered as rank 3, 30 to $50 \mathrm{~m}$ away from the drainage is considered as rank 2 and greater than $50 \mathrm{~m}$ away from the drainage rank1considered.(Table 11 ) 
Sustainability, Agri, Food and Environmental Research, (ISSN: 0719-3726), 10(X), 2022:

http://dx.doi.org/

Table 11. Drainage density classification

\begin{tabular}{llll}
\hline Parameter & Classification & Ranks & Weights \\
\hline Drainage & $0-0.35$ & 1 & 6 \\
Density & $\mathrm{km} / \mathrm{sq} . \mathrm{km}$ & & \\
& $0.99-1.67$ & 2 & \\
& $0.35-0.99$ & 3 & \\
& $1.67-2.80$ & 4 & \\
& $2.80-4.82$ & 5 & \\
\hline
\end{tabular}

- Weighted Overlay Analysis

The weighted overlay analysis was performed on a GIS platform to identify the suitable location for a solid waste processing unit. The prepared various thematic maps such as land use, geomorphology, geology, soil, lineament, groundwater table, water bodies, road, railway track, slope and drainage were used for weighted overlay analysis. The selection of criteria for identifying the suitable landfill site is based on the requirement in the particular region. Based upon the importance of the each feature weight has been assigned. In a weighted overlay analysis, GIS-based model was created to identify the suitable site for decentralized solid waste processing unit.

\section{RESULTS}

Reclassification method was used for each feature and reclassified based on its importance. The spatial analysis results (Figure 2) shows the suitable location in the south zone of Coimbatore city for a processing unit site. The suitable area in sqkm is identified under categories like highly suitable, high to moderately suitable, moderately suitable, poorly suitable and not suitable. The results are tabulated as shown (Table 12) 
Sustainability, Agri, Food and Environmental Research, (ISSN: 0719-3726), 10(X), 2022:

http://dx.doi.org/

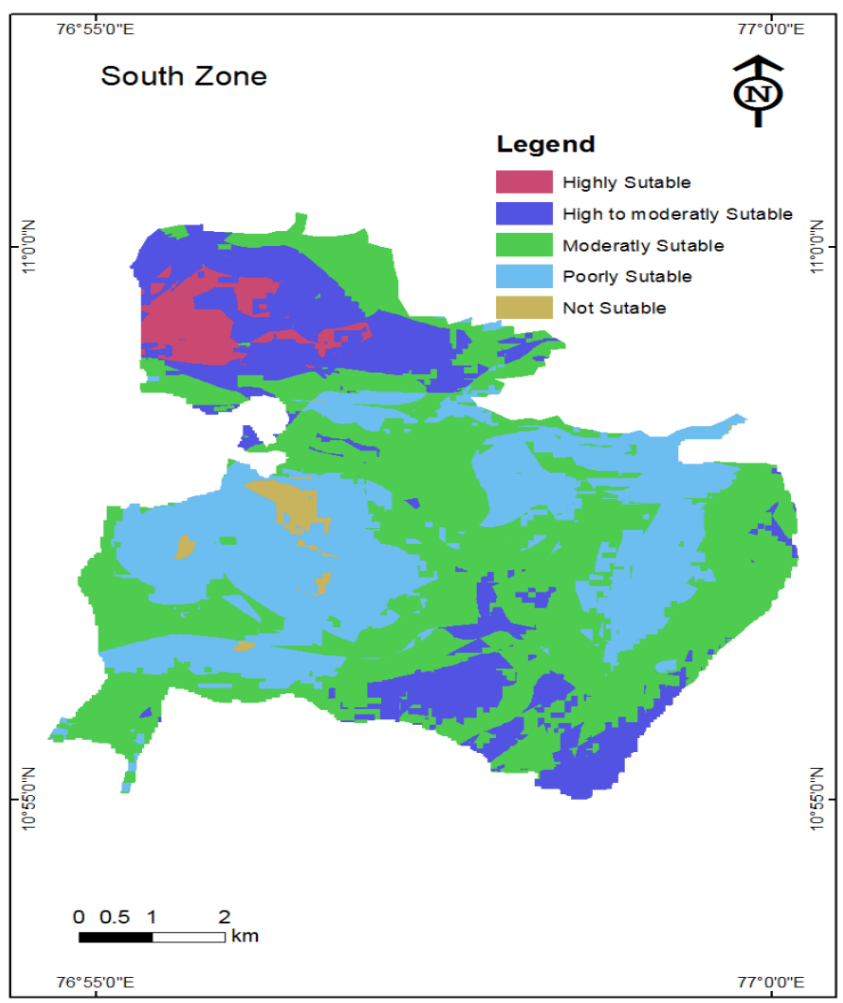

Figure 2 Site suitability map for Decentralized processing unit for solid waste in the study area

Table 12. Suitability analysis result

\begin{tabular}{lll}
\hline Zone & Classification & Area in Sqkm \\
\hline South zone & Highly suitable & 5 \\
& High to moderately suitable & 10 \\
& Moderately suitable & 22 \\
& Poorly suitable & 9 \\
& Not suitable & 2 \\
\hline
\end{tabular}

\section{CONCLUSION AND LIMITATIONS}

This model can be used for development of solid waste processing plant in south zone of Coimbatore city. This can assist the sanitary engineers to plan in future for decentralized solid waste plants in each region of the city. The limitation of this model is that field survey is required for getting current location of site shown in the model. The result displays the highly suitable, moderately suitable and not suitable spatial location in 
Sustainability, Agri, Food and Environmental Research, (ISSN: 0719-3726), 10(X), 2022:

http://dx.doi.org/

the study area. The result shows that the not suitable area is comparatively less hence there is more options to develop or install the processing plant in south zone of Coimbatore city, Tamil Nadu.

\section{REFERENCES}

Alanbari, M. A., Al-Ansari, N., and Jasim, H. K., "GIS and multicriteria decision analysis for landfill site selection in Al-HashimyahQadaa," Natural Science, 6(5), pp. 282-304, 2014.

Das, S., and Bhattacharyya, B. K., Estimation of municipal solid waste generation and future trends in greater metropolitan regions of Kolkata, India. Journal of Industrial Engineering and Management Innovation, 1(1), pp. 31-38, 2014.

Demesouka, O. E., Vavatsikos, A. P., and Anagnostopoulos, K. P., "Suitability analysis for siting MSW landfills and its multi-criteria spatial decision support system: method, implementation and case study," Waste management, 33(5), pp. 1190-1206, 2013.

Eiselt, H. A., and Marianov, V., "A bi-objective model for the location of landfills for municipal solid waste," European Journal of Operational Research, 235(1), pp. 187194, 2014.

Eskandari, M., Homaee, M., Mahmoodi, S., and Pazira, E., "Integrating GIS and AHP for municipal solid waste landfill site selection," Journal of Basic and Applied Scientific Research, 3(4), pp. 588-595, 2013.

Geneletti, D. "Combining stakeholder analysis and spatial multi-criteria evaluation to select and rank inert landfill sites," Waste Management, 30 (2), pp. 328-337, 2010.

Makan, A., Malamis, D., Assobhei, O., Loizidou, M., and Mountadar, M., Multi-criteria decision analysis for the selection of the most suitable landfill site: case of Azemmour, Morocco," International Journal of Management Science and Engineering Management, 7(2), pp. 96-109, 2012.

Nas, B., Cay, T., Iscan, F., and Berktay, A., "Selection of MSW landfill site for Konya, Turkey using GIS and multi-criteria evaluation," Environmental monitoring and assessment, 160(1), pp. 491-500, 2010

Pandey, B. K., Vyas, S., Pandey, M., and Gaur, A., "Characterisation of municipal solid waste generated from Bhopal, India," Curr. Sci. Perspect., 2, pp. 52-56, 2016.

Pramila, R., and Ramesh, K. V., "Biodegradation of low density polyethylene (LDPE) by fungi isolated from municipal landfill area," Journal of microbiology and biotechnology research, 1(4), pp. 131-136, 2017. 
Sustainability, Agri, Food and Environmental Research, (ISSN: 0719-3726), 10(X), 2022:

http://dx.doi.org/

Şener, Ş., Sener, E., and Karagüzel, R., "Solid waste disposal site selection with GIS and AHP methodology: a case study in Senirkent-Uluborlu (Isparta) Basin, Turkey," Environmental monitoring and assessment, 173(1), pp. 533-554, 2011.

Soltani, A., Hewage, K., Reza, B., and Sadiq, R., "Multiple stakeholders in multi-criteria decision-making in the context of municipal solid waste management: a review," Waste Management, 35, pp. 318-328, 2015.

Taha, M. R., Yaacob, W. Z. W., Samsudin, A. R., and Yaakob, J., "Groundwater quality at two landfill sites in Selangor, Malaysia," Bulletin of the Geological Society of Malaysia, 57, pp. 13-18, 2011.

Vuppala, P., Asadi, S. S., and Reddy, M. A., "Solid waste disposal site selection using analytical hierarchy process and geographical information system," Pollution Research, 25(1), pp. 73, 2006.

Yahaya, S., Ilori, C., Whanda, S., and Edicha, J., "Landfill site selection for municipal solid waste management using geographic information system and multi-criteria evaluation," American Journal of Scientific Research, 10, pp. 34-49, 2010.

Received: $15^{\text {th }}$ February 2021; Accepted: $18^{\text {th }}$ May 2021; First distributed: $18^{\text {th }}$ May 2021. 